Research Article

\title{
Post Bauxite Mining Land Soil Characteristics and Its Effects on the Growth of Falcataria moluccana (Miq.) Barneby \& J. W. Grimes and Albizia saman (Jacq.) Merr.
}

\author{
Ricksy Prematuri, ${ }^{1}$ Maman Turjaman, ${ }^{2}$ Takumi Sato, ${ }^{3}$ and Keitaro Tawaraya ${ }^{3}{ }^{3}$ \\ ${ }^{1}$ Research Centre for Bioresources and Biotechnology, Bogor Agricultural University, Kampus IPB Dramaga, \\ Bogor 16680, Indonesia \\ ${ }^{2}$ Forest Research and Development Centre, The Environment and Forestry Research and Development Agency (FORDA), \\ Jalan Gunung Batu No. 5, Bogor 16680, Indonesia \\ ${ }^{3}$ Faculty of Agriculture, Yamagata University, Tsuruoka 997-8555, Japan \\ Correspondence should be addressed to Keitaro Tawaraya; tawaraya@tds1.tr.yamagata-u.ac.jp
}

Received 11 September 2019; Revised 21 February 2020; Accepted 13 March 2020; Published 7 April 2020

Academic Editor: Teodoro M. Miano

Copyright (c) 2020 Ricksy Prematuri et al. This is an open access article distributed under the Creative Commons Attribution License, which permits unrestricted use, distribution, and reproduction in any medium, provided the original work is properly cited.

\begin{abstract}
The remediation of opencast bauxite mines in the natural forests of Indonesia is difficult. We have investigated and contrasted the chemical characteristics of soils from natural forests and mining sites and their effects on plant growth. The soil $\mathrm{pH}$, total carbon $(\mathrm{C})$, nitrogen $(\mathrm{N})$ and available phosphorus $(\mathrm{P})$ concentrations, cation exchange capacity, $\mathrm{C} / \mathrm{N}$ ratio, and exchangeable $\mathrm{K}, \mathrm{Na}, \mathrm{Mg}$, $\mathrm{Ca}, \mathrm{Fe}$, and $\mathrm{Ni}$ concentrations were determined. Falcataria moluccana and Albizia saman were then grown in these soils for 15 weeks, and their shoot heights, shoot dry weights, and root dry weights determined. The post bauxite mining soils' $\mathrm{N}$, C, and available $\mathrm{P}$ concentrations and exchangeable $\mathrm{Ca}, \mathrm{Mg}$, and $\mathrm{Na}$ concentrations decreased by $75,75.7,15.7,92,100$, and $52 \%$, respectively, in comparison with the natural forest soils. The shoot and root dry weights of $F$. moluccana when grown in the post bauxite mining soils were also lower than those from the natural forest soils. However, there was no difference in the shoot and root dry weights of A. saman when grown in the two soil types. The results suggest that opencast mining decreases the soil fertility, which in turn inhibits the initial growth of tree seedlings, and reduces the carbon stock in the land.
\end{abstract}

\section{Introduction}

The tropical rainforests on the Indonesian islands of the Riau Archipelago (Sumatera) vary greatly in their biodiversity but have soils that are generally poor in nutrients. In tropical rainforests, however, the biomass is the major pool for nutrients and not the forest soil content, as is found in temperate forests. While the material organic content of tropical soils is low overall, the decomposition processes on the forest floor and nutrient uptake are fast [1]. The organic carbon in tropical forests declined with depth, in the topsoil layer of East Kalimantan, Indonesia [2]. Information on soil characteristics in tropical rain forests, especially in Indonesia, is still very limited. Knowing the characteristics of the soil in tropical rainforests is important to take a strategic step in the process of rehabilitation of degraded land.

Forest land cover has been decreasing due to forest conversion into cropland, oil palm, rubber plantations, and opencast mining, in Indonesia [3]. Bauxite is important for aluminium production, and one of its main producers globally, via opencast mines, is Indonesia. The process of opencast mining consists of clearing vegetation, topsoil stripping, and mining for the minerals [4]. This process affects the landscape of the local environment and its social well-being, as it causes tremendous physical, chemical, and biological damage to forests, impacting on their vegetation and animal biodiversity [5]. Further, the removal of the top layer of soil causes loss of structure and functionality and a 
subsequent reduction in its biodiversity, resulting in socioeconomic impacts $[6,7]$. A study provides a selection of 20 forest plant native species for increasing biodiversity and restoration of area disturbed by petroleum extraction activities in the Ecuadorian Amazon [8].

The rehabilitation of postmining land is required to repair damage to local environments. Various methods are employed to achieve this, such as landscape reclamation, planting ground cover crops, utilization of fast-growing plants, and remediation of water and soil contaminants. As soil $\mathrm{pH}$ declines, the supply of most plant nutrients decreases, while aluminium and a few micronutrients become more soluble and toxic to plants. The problems are particularly acute in humid tropical forests that have been highly weathered. The soil $\mathrm{pH}$ beneath dipterocarp forests and plantations in East Kalimantan, Indonesia, were on average below 4 [9]. According to Sanchez and Logan [10], for example, one-third of the tropical forests, or 1.7 billion hectares, is acidic enough for soluble aluminium to be considered toxic for most crop plants. In tropical forests, deep tropical weathering and decomposition of rocks have caused excessive solution and leaching of bases, leaving insoluble $\mathrm{Fe}$ and $\mathrm{Al}$ sesquioxides.

The rehabilitation of tropical forest ecosystems disturbed by bauxite mining is the aim of an increasing number of programs in many parts of the world, including Indonesia. However, bauxite mining is an impermanent activity that has long-term negative effects on tropical forests [6]. During the process of opencast mining, all vegetation and topsoils are removed, the soil fertility in each horizon is shuffled, and chemical, physical, and biological conditions rapidly deteriorate. The removal of vegetation and the disturbance of the soil profile reduce the nutrient pools available for seedling trees during mine site rehabilitation [7]. Forest soil compaction and erosion increase surface flow, flooding, and droughts in natural dipterocarp forests and the forest plantation industry in East Kalimantan, Indonesia [9]. The number of plant species and the amount of cover vegetation are thus found to be lower in post bauxite mining land than in those of natural forests.

Typically, bauxite is covered by a thick lateritic zone. This lateritic zone is completely removed to access the bauxite ore. Bauxite mining processes consist of blasting, removal of ore, and the movement of heavy vehicles that alter the soils physical and chemical properties [6]. The chemical properties of post bauxite mining soils can be strongly influenced by the presence of vegetation and tree species. It is necessary to know the chemical characteristics of the soil in post opencast mining land before implementing rehabilitation programs.

Selecting fast-growing tropical trees is important to increase the success rate of rehabilitation in degraded mining lands. Falcataria moluccana (Miq.) Barneby \& J. W. Grimes and Albizia saman (Jacq.) Merr. are two tropical fast-growing species that are intensively grown to support rehabilitation programs of industrial forest plantations in Southeast Asia. F. moluccana is native to Molluca, New Guinea, the Bismark Archipelago, and the Solomon Islands and has been recognized as a multipurpose species as it can be used for pulp and paper, fuel wood, and ornamental plantings, as a shade tree, and as a nitrogen supplier to soils [11]. A. saman is an important species used in the furniture and craftwork industries and has moderate wood density, attractive wood color, excellent workability properties, and natural durability, is considered a shade tree, and is also useful for animal feed [12]. It is necessary to select plant species that adapt to degraded post-opencast mining lands. The rehabilitation of postmining lands starts with rebuilding the soils biological capacity, mineral nutrient cycling, and establishment of plant communities [13]. Dissemination of successful rehabilitation activities on postmining land requires new collaborative science and technology-driven innovations [14].

The purpose of this study was to clarify the effects of opencast bauxite mining on the chemical characteristics of soil and its effect on the plant growth of F. moluccana and A. saman under greenhouse conditions.

\section{Materials and Methods}

2.1. Study Site and Soil Sampling. Soil was collected from both a natural Adinandra belukar forest, a secondary succession after cleared land exploitation of the primary lowland rain forest [9], and a post bauxite mining site, on Bintan Island, Sumatera, on 10 May 2011 (Figure 1). The samples were collected from 3 samplings points at the natural forest site of Adinandra belukar $\left(0^{\circ} 52^{\prime} 21^{\prime \prime} \mathrm{N}, 104^{\circ} 39^{\prime} 02^{\prime \prime} \mathrm{E}\right)$ and 3 samplings point at the postmining site $\left(0^{\circ} 49^{\prime} 22^{\prime \prime} \mathrm{N}\right.$, $104^{\circ} 39^{\prime} 61^{\prime \prime} \mathrm{E}$ ) (Figure 2). Surface litter, fine roots, and stones were scraped away before taking the soil samples, and soils were collected from each sector at a depth of $0-25 \mathrm{~cm}$. Fifteen soil samples from 3 randomized sampling points of the natural forest and 15 soil samples from 3 randomized sampling points of the postmining land were collected with a hand scoop, mixed, and placed in a clean plastic bag. A smaller portion of theses homogenized samples (approximately $1000 \mathrm{~kg}$ ) was diced and ground before laboratory analysis.

2.2. Soil Chemical Analysis. The soil samples were air-dried, passed through a $<2 \mathrm{~mm}$ sieve, and used for the analysis of $\mathrm{pH}\left(\mathrm{H}_{2} \mathrm{O}\right)$ and $\mathrm{pH}(\mathrm{KCl})$. The use of the two methodologies for the measurement of $\mathrm{pH}$ was to indicate the presence of exchangeable protons or ions in the soil. The $\mathrm{pH}\left(\mathrm{H}_{2} \mathrm{O}\right)$ shows the actual $\mathrm{pH}$ of the solution in the soil while $\mathrm{pH}$ $(\mathrm{KCl})$ is a potential $\mathrm{pH}$ of soil indicating $\mathrm{pH}$ in the soil solution and soil bonding complex. In $\mathrm{pH}$ potential, $\mathrm{H}^{+}$ions are measured more than the actual $\mathrm{pH}$. Furthermore, $\mathrm{pH}$ $(\mathrm{KCl})$ was compared with $\mathrm{pH}\left(\mathrm{H}_{2} \mathrm{O}\right)$. Available phosphate (P) [15] was extracted with a $0.001 \mathrm{M}$ sulfuric acid solution and analyzed using the ammonium molybdate method. Total carbon (TC) and total nitrogen (TN) were determined by a C:N analyzer (Sumigraph NC-220F, Tokyo). Exchangeable potassium, sodium, magnesium, and calcium were extracted with $1 \mathrm{M}(\mathrm{pH}$ 7) ammonium acetate solution, and their concentrations were determined using an atomic absorption spectrophotometer (Hitachi model Z-5000 series 


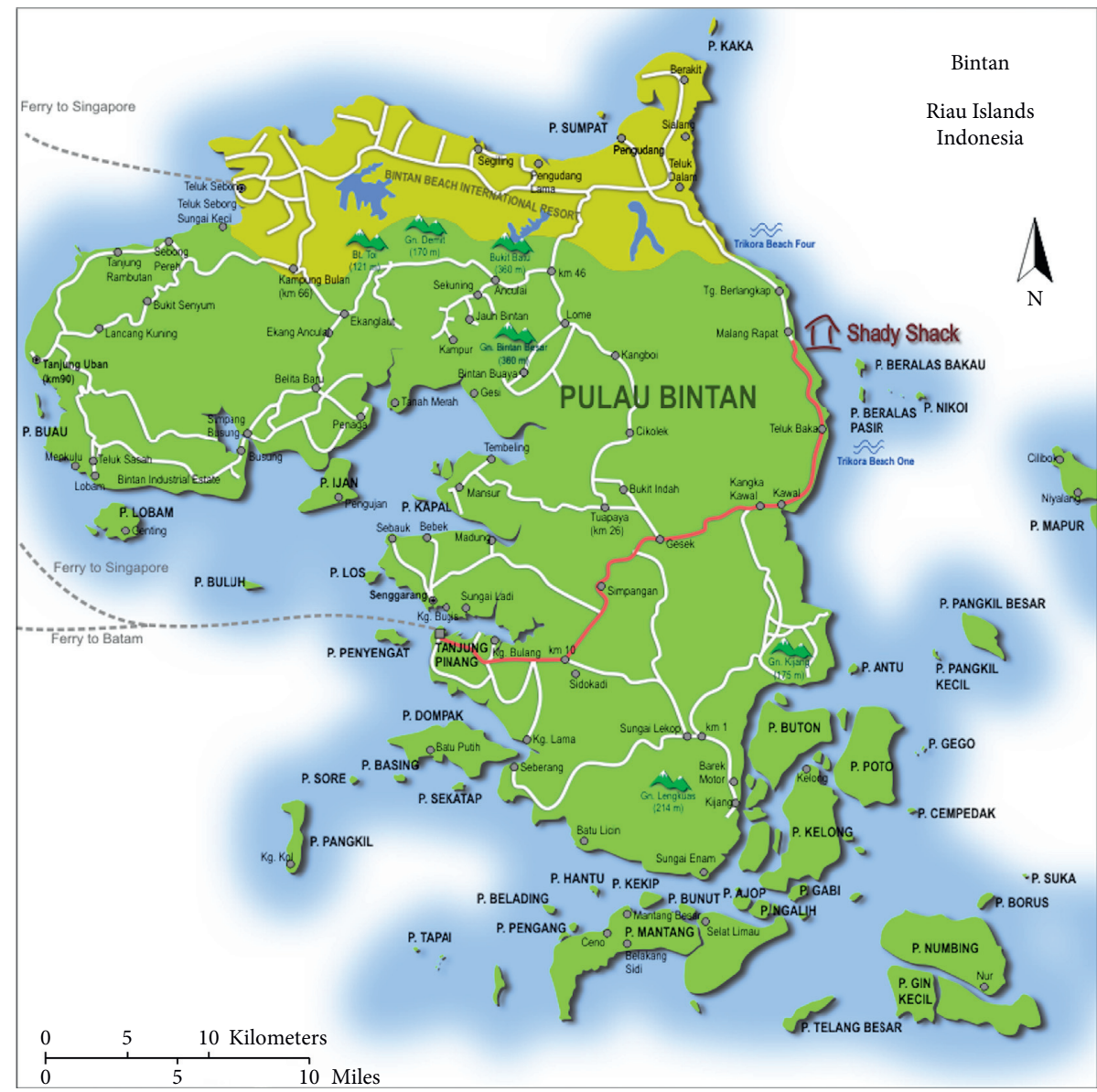

FIgure 1: Map of Bintan Island, Indonesia.

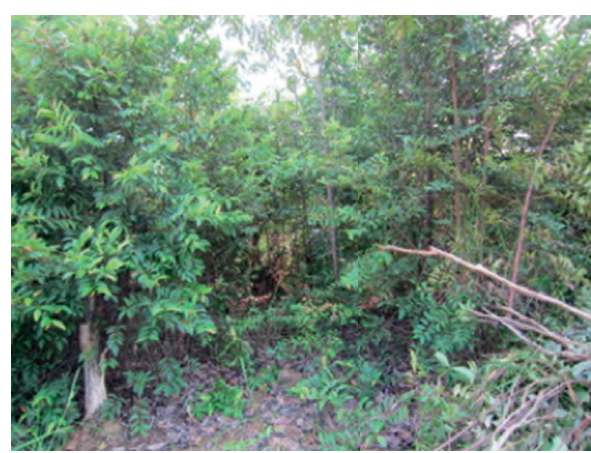

(a)

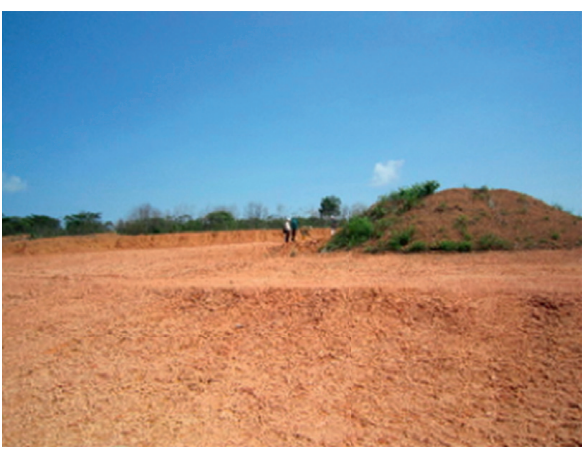

(b)

Figure 2: (a) Natural forest and (b) post-opencast bauxite mining land, Bintan Island, Indonesia.

Polarized Zeeman, Tokyo). The sample was extracted with $100 \mathrm{~g} \cdot \mathrm{L}^{-1}$ potassium chloride solution, and the supernatant was used to determine the cation-exchange capacity (CEC) using the semi-micro-Schöllenberger method.

2.3. Plant Growth. Two tropical forest trees, Falcataria moluccana and Albizia saman, were selected for this study. Seeds of both species were purchased from a local seed company, Solo, Central Java, Indonesia. The seeds were soaked in water at $80^{\circ} \mathrm{C}$ for $2 \mathrm{~min}$ and were then pregerminated in a plastic bag using zeolite as a growth medium. After the radicles appeared, they were selected for uniformity before sowing. Two-hundred grams of each soil was placed into polyethylene pots $(7.5 \mathrm{~cm}$ height $\times 5 \mathrm{~cm}$ diameter), and the pots were placed in a randomized block design. Seedlings (three weeks old) were transplanted for each treatment. The experiment was conducted from July to October 2011, in the greenhouse at the Forest and Nature Conservation Research and Development Centre, Bogor, 
West Java $\left(6^{\circ} 36^{\prime \prime} \mathrm{S}, 106^{\circ} 45^{\prime \prime} \mathrm{E}\right)$. The temperature varied between 26 to $35^{\circ} \mathrm{C}$, relative humidity was 80 to $90 \%$, and the photoperiod was about $12 \mathrm{~h}$. The plants were grown for 15 weeks. Deionized water was added as required to maintain the moisture content to field capacity, by slowly pouring water over the pot that contains the plant, until the water excesses come out from the bottom of the pot.

2.4. Harvest and Analysis of Plants. Shoot height, from one $\mathrm{cm}$ above the soil surface, was measured every 2 weeks, until 15 weeks after transplanting when plants were harvested and the shoots and roots were separated. The shoots were ovendried at $70^{\circ} \mathrm{C}$ for $72 \mathrm{~h}$, and the shoot dry weight was measured.

2.5. Statistical Analysis. All experiments were laid out in a random block design with fifteen replicates. All the data were analyzed with Student's $t$-test, using the Minitab package (Minitab, U.S.A.). When $F$ values were significant, the least significant difference test (LSD) was used to compare the significant differences between treatment means.

\section{Results}

3.1. Soil Chemical Characteristics of the Natural Forest and Post Bauxite Mining Land. The soil $\mathrm{pH}(\mathrm{KCl})$ of the postmining land was higher than that of the natural forests (Table 1), but there was no difference between the soils for $\mathrm{pH}\left(\mathrm{H}_{2} \mathrm{O}\right)$. Total nitrogen, carbon, and available $\mathrm{P}$ concentrations in the soils of the postmining lands were lower than those in the natural forests, and the $\mathrm{C} / \mathrm{N}$ ratio was higher. The CEC was not different between the postmining land and the natural forest. The exchangeable $\mathrm{Ca}, \mathrm{Mg}$, and $\mathrm{Na}$ concentrations of the postmining land were lower than those of the natural forest, and there was no difference in the exchangeable $\mathrm{K}, \mathrm{Fe}$, and $\mathrm{Ni}$ concentrations.

3.2. Growth of Falcataria moluccana and Albizia saman in Natural Forests and Postmining Land. Shoot height of the F. moluccana grown in both the natural forest and postmining soils increased from 2 to 15 weeks after planting (Figure 3(a)); however, 2, 4, 13, and 15 weeks after planting, those on the postmining soil were shorter compared with those in the natural forest soils. Shoot height of the A. saman seedlings in both the natural forest and postmining soils also increased from 2 to 15 weeks after planting (Figure 3(b)); however, $8,10,13$, and 15 weeks after planting, those on the postmining soil were shorter compared with those in the natural forest soils.

The shoot and root dry weights, 15 weeks after transplanting, for the F. moluccana grown in the postmining soils, were lower than those in the natural forest (Figure 3 ). There was no difference in the shoot and root dry weights for $A$. saman for the different soil treatments (Figure 4).

\section{Discussion}

4.1. Effect of Opencast Bauxite Mining on Soil Chemical Characteristics. Opencast bauxite mining decreased the soil fertility overall and the TN concentrations by $75 \%$ (Table 1). The reduction was due to the removal of tree cover, litter, and topsoil by the processes used to create the opencast mines. The reduction was higher than the $53 \%$ reduction reported for soil from an opencast coal mining site in India [16] and the $53-80 \%$ reduction in soil from an opencast coal mining site in the U.S.A. [17]. The effect of opencast mining on soil fertility in tropical areas is higher than that in nontropical areas. The reduction in $\mathrm{TN}$ was also higher than the $45 \%$ reduction in farmland compared with forests [18] and the $36 \%$ reduction after forest fires [19]. Deforestation by opencast mining overall affected soil fertility more severely than the other causes of deforestation.

The soil fertility of the postmining soils in Bintan Island was very poor in comparison to the natural soil. The soil $\mathrm{pH}$ is an important factor to support the growth of plants [20]. The $\mathrm{pH}$ of the postmining soils of the Bintan Island soils varied from $4.96 \pm 0.05$ for $\mathrm{pH}\left(\mathrm{H}_{2} \mathrm{O}\right)$ and $4.52 \pm 0.09$ for $\mathrm{pH}$ $(\mathrm{KCl})$. The $\mathrm{pH}$ of $\mathrm{KCl}$ was lower than the $\mathrm{pH}$ of $\mathrm{H}_{2} \mathrm{O}$. These results could indicate the presence of exchangeable protons or ions in the soil. The soil can hold the cation exchanged in the plants. The $\mathrm{pH}$ of $\mathrm{H}_{2} \mathrm{O}$ and $\mathrm{pH}$ of $\mathrm{KCl}$ of the postmining soils of the Bintan Island, however, were higher compared to the average soil $\mathrm{pH}$ of 3.6 from the Adinandra belukar in Singapore [9] and the acrisols beneath the dipterocarp forest and plantation in East Kalimantan, that had $\mathrm{pH}$ values from 3.70 to 3.75 [2]. Because the soil $\mathrm{pH}$ of postmining land of Bintan Island were higher compared with the Adinandra belukar in Singapore, and the location of Bintan Island is geography adjacent to Singapore, thus reforestation of post bauxite mining land of Bintan Island may approachable by using a type of plant that grows in the Adinandra belukar in Singapore, such as Adinandra Dumosa, Dillenia Suffruticosa, and Fragraea fragrans [9]. Reforestation may also be approachable by the species plant from the dipterocarp forest. The total $\mathrm{N}$ of the postmining of Bintan Island was $0.4 \pm 0.2$ $(\mathrm{g} / \mathrm{kg})$. It was lower than the total $\mathrm{N}$ of $0.08(\%)$ of Adinandra belukar in Singapore [9] and $1.5 \pm 0.6(\mathrm{mg} / \mathrm{g})$ of $\mathrm{N}$ at heat forest on Gunung Keriong, Pahang, Malaysia [21]. The species of nitrogen-fixing from leguminous trees could be used for reforestation of post bauxite mining land in Bintan Island with low of TN concentrations. The introduction of leguminous trees are able to form symbioses with nodulating $\mathrm{N}_{2}$-fixing bacteria. The successful results using of nitrogenfixing legume trees for the reclamation of areas degraded by mining activities in Brazil have been reported [22]. Soil physical characteristics can be different between natural soil and postmining soil and can affect the growth of plants.

4.2. Reduction in Carbon Stock by Bauxite Mining. Total C concentrations of the post bauxite mining soils were lower than those of the natural forest soils. The removal of the topsoil from a post bauxite mining site and mixing it with the underlying soil considerably reduced the relative proportion of organic carbon. The $\mathrm{C}$ concentration in the post bauxite mining soils was $0.7 \pm 0.2 \%$; this range included in the level of organic carbon in overburden was found to be $0.35 \%$ to $0.85 \%$ [23]. $\mathrm{C}$ is an important parameter for any 
TABle 1: Chemical characteristics of the soils from the natural forests and post bauxite mining land.

\begin{tabular}{|c|c|c|c|c|c|c|c|c|c|c|c|c|c|c|c|c|c|c|c|c|c|c|c|c|c|}
\hline \multirow{2}{*}{$\begin{array}{l}\text { Location } \\
\text { Natural forest }\end{array}$} & \multicolumn{2}{|c|}{$\mathrm{pH}\left(\mathrm{H}_{2} \mathrm{O}\right)$} & \multicolumn{2}{|c|}{ PH (KCl) } & \multicolumn{2}{|c|}{$\begin{array}{c}\text { Total } \\
\text { carbon } \\
(\mathrm{g} / \mathrm{kg})\end{array}$} & \multicolumn{2}{|c|}{$\begin{array}{c}\text { Total } \\
\text { nitrogen } \\
(\mathrm{g} / \mathrm{kg})\end{array}$} & \multicolumn{2}{|c|}{$\mathrm{C} / \mathrm{N}$ ratio } & \multicolumn{2}{|c|}{$\begin{array}{c}\text { Available } \\
\mathrm{P} \\
\left(\mathrm{mgP}_{2} \mathrm{O}_{5} /\right. \\
\mathrm{kg})\end{array}$} & \multicolumn{2}{|c|}{$\begin{array}{c}\mathrm{CEC} \\
(\mathrm{cmol} / \mathrm{kg})\end{array}$} & \multicolumn{2}{|c|}{$\underset{(\mathrm{mg} / \mathrm{kg})}{\mathrm{Ca}}$} & \multirow{2}{*}{$\begin{array}{c}\begin{array}{c}\mathrm{Mg} \\
(\mathrm{mg} / \mathrm{kg})\end{array} \\
1.82\end{array}$} & \multicolumn{2}{|c|}{$\underset{(\mathrm{mg} / \mathrm{kg})}{\mathrm{K}}$} & \multicolumn{2}{|c|}{$\begin{array}{c}\mathrm{Na} \\
(\mathrm{mg} / \mathrm{kg})\end{array}$} & \multicolumn{2}{|c|}{$\underset{(\mathrm{mg} / \mathrm{kg})}{\mathrm{Fe}}$} & \multicolumn{2}{|c|}{$\begin{array}{c}\mathrm{Ni} \\
(\mathrm{mg} / \mathrm{kg})\end{array}$} \\
\hline & 5.06 & $\mathrm{a}$ & 3.99 & b & 2.88 & $\mathrm{a}$ & 1.6 & a & 19.0 & $\mathrm{~b}$ & 13.4 & $\mathrm{a}$ & 12.75 & a & 11.24 & $\mathrm{a}$ & & 38.04 & $\mathrm{a}$ & 1.35 & $\mathrm{a}$ & 4.49 & $\mathrm{a}$ & 7.82 & a \\
\hline SE & 0.07 & & 0.04 & & 4.1 & & 0.3 & & 0.9 & & 0.2 & & 1.71 & & 0.29 & & 0.74 & 19.39 & & 0.52 & & 0.52 & & 1.02 & \\
\hline Postmining & 4.96 & a & 4.52 & $\mathrm{a}$ & 7.0 & b & 0.4 & b & 39.4 & a & 11.3 & b & 8.90 & $\mathrm{a}$ & 0.92 & b & $\mathrm{bdl}^{*}$ & 81.54 & b & 0.65 & b & 3.72 & a & 5.72 & a \\
\hline SE & 0.05 & & 0.09 & & 2.5 & & 0.2 & & 8.8 & & 0.1 & & 2.44 & & 0.22 & & & 45.05 & & 0.08 & & 0.18 & & 1.52 & \\
\hline
\end{tabular}

Different letters within column indicate a significant differences $(P<0.05)$ by the $t$ test. Mean \pm standard error (SE) is shown $(n=15)$. ${ }^{*}$ bdl: below the detection limit.

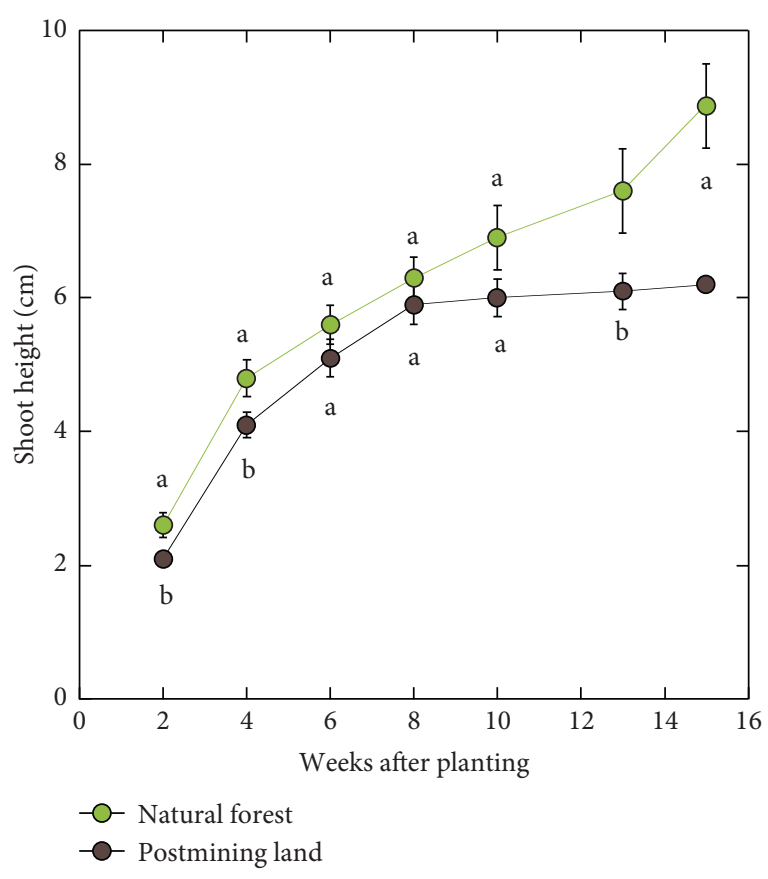

(a)

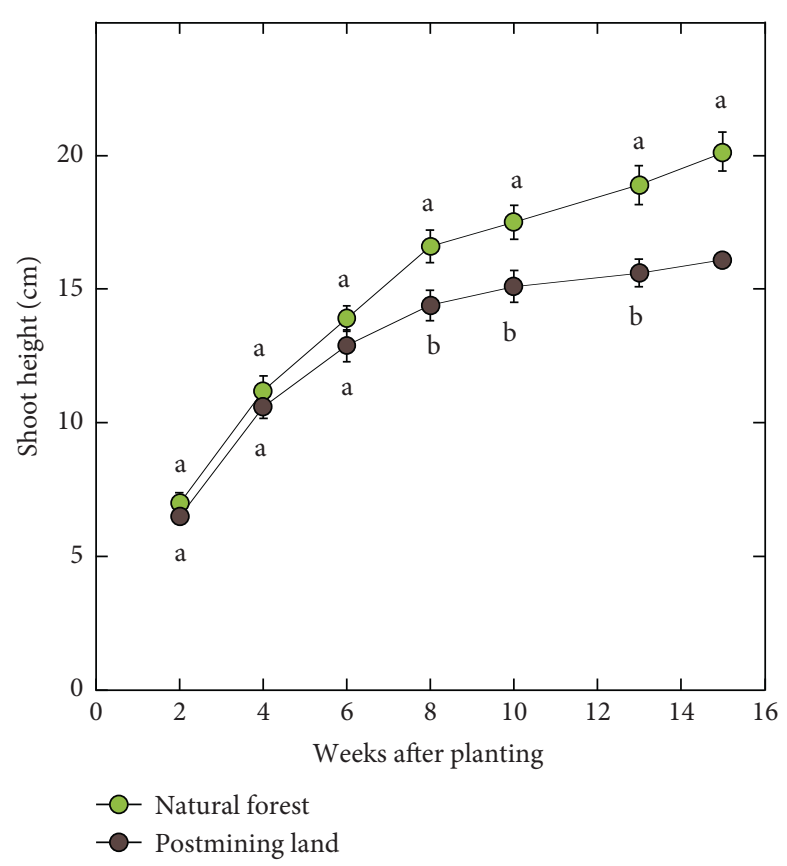

(b)

Figure 3: Shoot height of Falcataria moluccana (a) and Albizia saman (b) grown on natural forest soils and post bauxite mining soils for 15 weeks under greenhouse conditions. Different letters of each week indicate a significant difference $(P<0.05)$ by the $t$ test. Mean \pm standard error is shown $(n=15)$.

soil, as it improves both the physical and chemical properties of the soil and has several favorable effects on soil quality. The advantages and functions of natural forest ecosystems are, for example, wildlife habitats, erosion, and flood defenses, water regulator, carbon sequestration, protecting shallow water ecosystems such as coral reefs and seagrass beds, and so forth [24]. Therefore, the forest type significantly affects the soil physicochemical property of the soil's microbial biomass carbon, nitrogen, and phosphorous [25]. It could be applied to the organic compost to increase C concentration in post bauxite mining for the rehabilitation activities. The use of organic fertilizers of chicken manure increases the organic $\mathrm{C}$ in the soil. It is better than that of cow manure and organic litter compost on Samanea saman tree on postmining land [26].

4.3. Growth of Plant in Post-Opencast Mining Land. Shoot dry weight of both F. moluccana and A. saman decreased in the postmining soils, but the degree of the decrease was different between the two species (Figures 4 and 5). A. saman seedlings were more tolerant than the $P$. moluccana in the postmining soils after 15 weeks of growth under greenhouse conditions. The soil chemical characteristics, such as $\mathrm{pH}$, are important factors to determine the growth of plants in soil postmining [20]. A. saman adapts to a wide range of soil types and $\mathrm{pH}$ levels, has a massive root system that expands both horizontally and vertically [27], can grow in soils that are free draining or those that have impeded drainage, can sometimes tolerate growth under waterlogged conditions, and finally, can grow in slightly acidic to neutral $\mathrm{pH}$ (6.0-7.4) soils while tolerating $\mathrm{pH}$ values as high as 8.5 and as low as 4.7. These characteristics of $A$. saman indicate that it would be ideal to use for the reforestation of post bauxite mining land. Many studies of postmining land in Africa have proven that pioneer leguminous trees show good adaptations and higher survival rates [28]. After F. moluccana and A. saman are established and grow well in post bauxite 


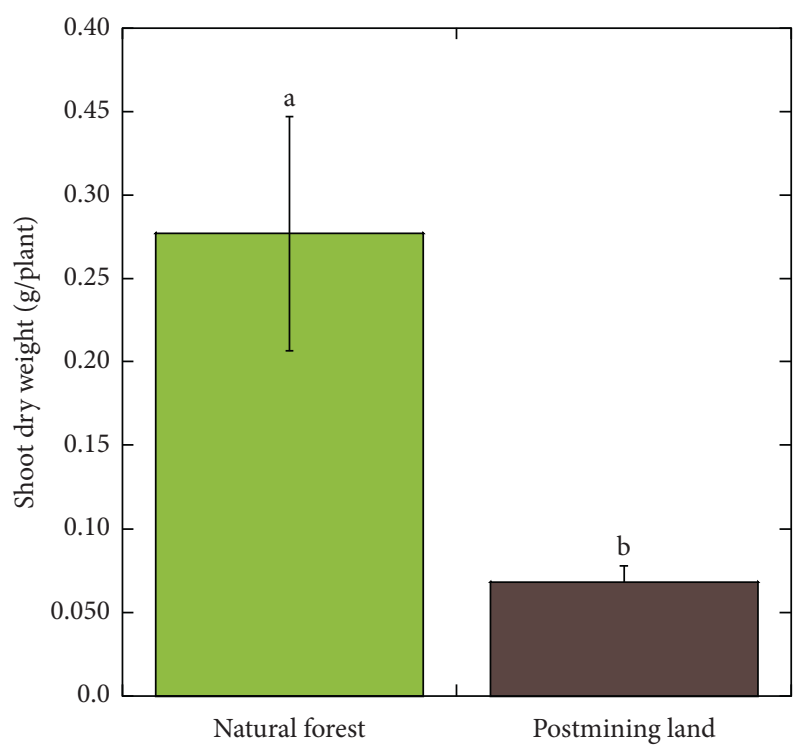

(a)

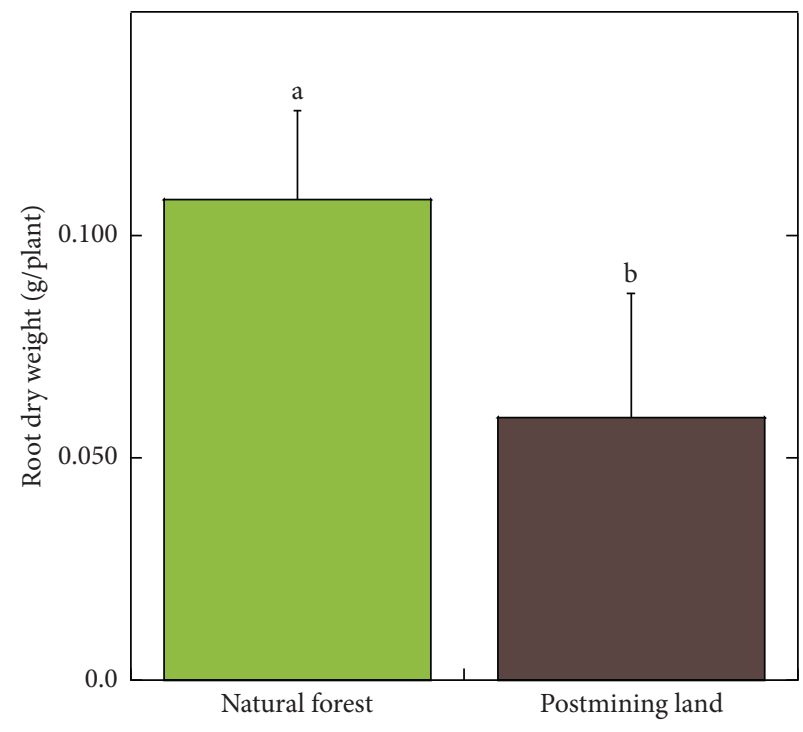

(b)

Figure 4: Shoot dry weight (a) and root dry weight (b) of Falcataria moluccana grown on natural forest soils and post bauxite mining soils for 15 weeks under greenhouse conditions. Different letters of each column chart indicate a significant difference $(P<0.05)$ by the $t$ test. Mean \pm standard error is shown $(n=15)$.

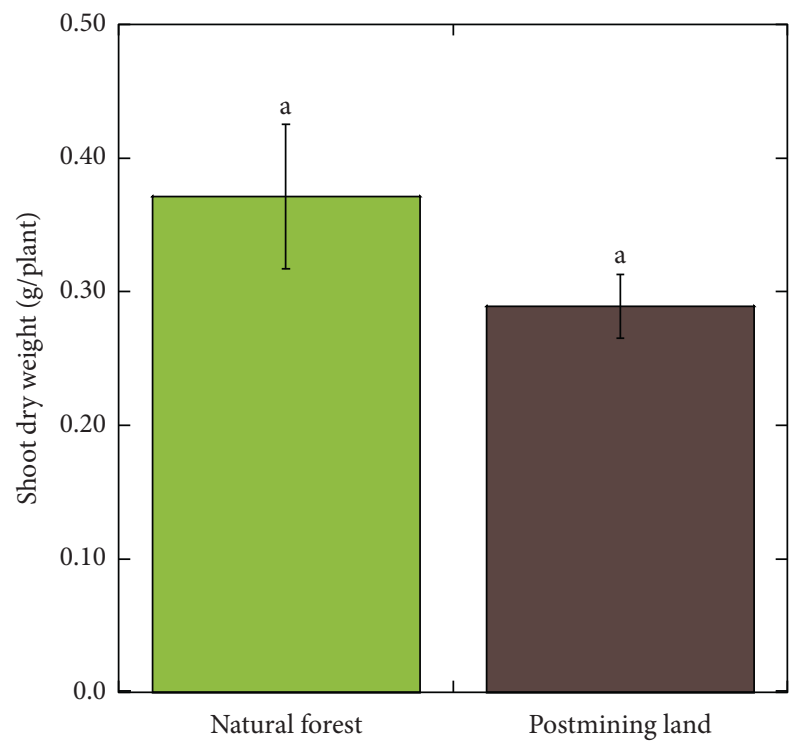

(a)

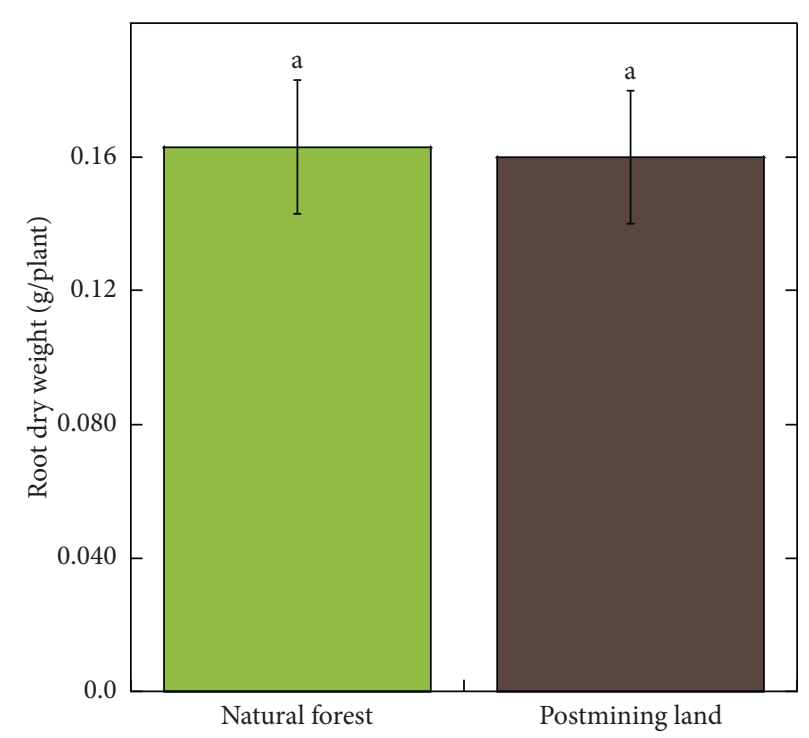

(b)

FIGURE 5: Shoot dry weight (a) and root dry weight (b) of Albizia saman grown on natural forest soils or post bauxite mining soils for 15 weeks under greenhouse conditions. Different letters of each column chart indicate a significant difference $(P<0.05)$ by the $t$ test. Mean \pm standard error is shown $(n=15)$.

mining lands, there will be enrichment plantation using local species, including lots of local fast-growing trees species such as Jacaranda obtusifolia, Macaranga bancana, Macaranga conifera, and Macaranga gigantean. These species were identified as suitable in previous research if good quality and quantities of seeds can be sourced [29]. The bauxite mining activities decreased the fertility of natural forest soil. The application of fertilizer to improve soil fertility of post- opencast mining land and the inoculation of effective microorganisms to increase the initial growth of tree species are necessary for the rehabilitation of post bauxite mining land. This strategy of rehabilitation activity is to develop bioindicators of hydro-geochemical and reconstruct root zones, which can enhance the recovery of the microorganism communities and ecological networks with rehabilitated plant communities in post bauxite mining land [13]. F. 
moluccana and A. saman are widely used rehabilitation of disturbed land in Indonesia. The present result shows that $A$. saman is more suitable for the rehabilitation of post bauxite mining land. Growth response of plants in post opencast mining land should also be investigated under field conditions.

\section{Conclusions}

Soil fertility of opencast bauxite mining land was lower than that in the natural forests in Indonesia. Organic carbon concentrations were also lower in the opencast bauxite mining land than in the natural forest, suggesting a reduction in carbon stock by opencast mining. The soil fertility of post bauxite mining soils for total $\mathrm{N}, \mathrm{C}$, available $\mathrm{P}$ concentrations, exchangeable $\mathrm{Ca}, \mathrm{Mg}$, and $\mathrm{Na}$ concentrations decreased by $75,75.7,15.7,92,100$, and $52 \%$, respectively. Reduced soil fertility in post bauxite mining land decreased the growth of tree species. However, A. saman seemed to be the more tolerant tree species for rehabilitation on post bauxite mining land.

\section{Data Availability}

The data used to support the findings of this study are available from the corresponding author upon request.

\section{Conflicts of Interest}

The authors declare no conflicts of interest.

\section{Acknowledgments}

The authors express gratitude to JSPS Ronpaku (Japan) for providing the support to carry out this research. The authors are also grateful to Mr. Hendro Guntoro from PT Green Planet Indonesia, Mrs Ratna Irdiastuti, Mrs Desi Maryanti, from PT Performa Qualita Mandiri, Bogor Indonesia, and Ms. Noor F. Mardatin from the Research Centre for Bioresource and Biotechnology, Bogor Agriculture University, Indonesia.

\section{References}

[1] T. C. Whitmore, An Introduction to Tropical Rain Forests, OUP, Oxford, UK, 2nd edition, 1998.

[2] W. W. Wenzel, H. Unterfrauner, A. Schulte et al., "Hydrology of acrisols beneath dipterocarp forest and plantation in East Kalimantan, Indonesia," in Soil of Tropical Forest Ecosystems: Characteristic, Ecology and Management 1998, A. Schulte and D. Ruhiyat, Eds., Springer, Berlin, Germany, pp. 62-72, 1998.

[3] C. van der Laan, A. Budiman, J. Verstegen et al., "Analyses of land cover change trajectories leading to tropical forest loss: illustrated for the West Kutai and Mahakam Ulu districts, East Kalimantan, Indonesia,” Land, vol. 7, no. 3, p. 108, 2018.

[4] M. K. Ghose and S. R. Majee, "Assessment of dust generation due to opencast coal mining-an Indian case study," Environmental Monitoring and Assessment, vol. 61, pp. 255-263, 2000.

[5] M. D. Craig, R. J. Hobbs, A. H. Grigg et al., "Do thinning and burning sites revegetated after bauxite mining improve habitat for terrestrial vertebrates?" Restoration Ecology, vol. 18 , no. 3, pp. 300-310, 2009.

[6] R. J. Lad and J. S. Samant, "Impcat of bauxite mining on soil: a case study of bauxite mines at Udgiri, dist-Kohhapur, Maharashtra stete, India," International Research Journal of Environmental Sciences, vol. 4, pp. 77-83, 2015.

[7] M. I. Daws, R. J. Standish, J. M. Koch, and T. K. Morald, "Nitrogen and phosphorus fertilizer regime affect jarrah forest restoration after bauxite mining in Western Australia," Applied Vegetation Science, vol. 16, no. 4, pp. 610-618, 2013.

[8] J. Villacís, F. Casanoves, S. Hang, S. Keesstra, and C. Armas, "Selection of forest species for the rehabilitation of disturbed soils in oil fields in the Ecuadorian Amazon," Science of the Total Environment, vol. 566-567, pp. 761-770, 2016.

[9] J. W. S. Sim, H. T. W. Tan, and I. M. Turner, "Adinandra belukar: an anthropogenic heath forest in Singapore," Vegetatio, vol. 102, no. 2, pp. 125-137, 1992.

[10] P. A. Sanchez and T. J. Logan, "Myths and science about the chemistry and fertility of soils in the tropics," in Myths and Science of Soils of the Tropics, R. Lal and P. A. Sanchez, Eds., vol. 29, pp. 35-46, Soil Science Society of America, Madison, WI, USA, 1992.

[11] H. Krisnawati, E. Varis, M. Kallio, and M. Kanninen, Paraserianthes Falcataria (L.) Nielsen Ecology, Silviculture and Productivity, Center for International Forestry Research, Bogor, Indonesia, 2011.

[12] D. C. Delgado, R. Hera, J. Cairo, and Y. Orta, "Samanea saman, a multi-purpose tree with potentialities as alternative feed for animals of productive interest," Cuban Journal of Agricultural Science, vol. 48, pp. 205-212, 2014.

[13] L. Huang, T. Baumgartl, and D. Mulligan, "Is rhizosphere remediation sufficient for sustainable revegetation of mine tailings?” Annals of Botany, vol. 110, no. 2, pp. 223-238, 2012.

[14] A. T. Cross, J. C. Stevens, and K. W. Dixon, "One giant leap for mankind: can ecopoiesis avert mine tailings disasters?" Plant and Soil, vol. 421, no. 1-2, pp. 1-5, 2017.

[15] E. Truog, "The determination of the readily available phosphorus of soils," Agronomy Journal, vol. 22, no. 10, pp. 874-882, 1930.

[16] R. S. Singh, N. Tripathi, and S. K. Chaulya, "Ecological study of revegetated coal mine spoil of an Indian dry tropical ecosystem along an age gradient," Biodegradation, vol. 23, no. 6, pp. 837-849, 2012.

[17] R. K. Shrestha and R. Lal, "Changes in physical and chemical properties of soil after surface mining and reclamation," Geoderma, vol. 161, no. 3-4, pp. 168-176, 2011.

[18] M. A. Hajabbasi, A. Jalalian, and H. R. Karimzadeh, "Deforestation effects on soil physical and chemical properties, Lordegan, Iran," Plant and Soil, vol. 190, no. 2, pp. 301-308, 1997.

[19] A. Sitlhou and T. B. Singh, "Post-fire nutrient availability in the sub-tropical forest ecosystem of the Koubru Hills, Manipur," F1000Research, vol. 3, p. 30, 2014.

[20] K. Sena, C. Agouridis, J. Miller, and C. Barton, "Spoil type influences soil genesis and forest development on an Appalachian surface coal mine ten years after placement," Forests, vol. 9, no. 12, p. 780, 2018.

[21] G. L. S. Chua, B. L. Koh, S. Lau et al., "The nutrient status of the plateau heath forest on Gunung Keriong, Pahang, peninsular Malaysia," Journal of Tropical Forest Science, vol. 8, no. 2, pp. 240-246, 1995.

[22] G. M. Chaer, A. S. Resende, E. F. C. Campello, S. M. de Faria, and R. M. Boddey, "Nitrogen-fixing legume tree species for the reclamation of severely degraded lands in Brazil," Tree Physiology, vol. 31, no. 2, pp. 139-149, 2011. 
[23] V. Sheoran and A. S. Sheoran, "Soil reclamation of abadoned mine land by revegetation: a review," International Journal of Soil, Sediment and Water, vol. 3, pp. 1-21, 2010.

[24] B. Wasis, "Soil properties in natural forest destruction and conversion to agricultural land, in Gunung Leuser national park, north Sumatera province," Jurnal Manajemen Hutan Tropika (Journal of Tropical Forest Management), vol. 18, no. 3, pp. 206-212, 2012.

[25] L. R. Chandra, S. Gupta, V. Pande, and N. Singh, "Impact of forest vegetation on soil characteristics: a correlation between soil biological and physico-chemical properties," 3 Biotech, vol. 6, no. 2, p. 188, 2016.

[26] S. Darma, W. Kustiawan, D. Ruhiyat, and Sumaryono, "Organic fertilizers improves Trembesi (Samanea saman) seedling growth, a case study of the implementation of postmining land reclamation and revegetation within the forest cultivation zone," International Journal of Scientific and Technology Research, vol. 6, pp. 393-399, 2017.

[27] M. Z. Haq, M. Robbani, M. Ali et al., "Damage and management of cyclone sidr-affected homestead tree plantations: a case study from Patuakhali, Bangladesh," Natural Hazards, vol. 64, no. 2, pp. 1305-1322, 2012.

[28] E. S. Festin, M. Tigabu, M. N. Chileshe, S. Syampungani, and P. C. Odén, "Progresses in restoration of post-mining landscape in Africa," Journal of Forestry Research, vol. 30, no. 2, pp. 381-396, 2019.

[29] C. M. Boo, S. Y. J. Chew, and J. W. H. Yong, Plants in Tropical Cities, Uvaria Tide, Singapore, 1st edition, 2014, http://www. uvariatide.com/publication/. 